\title{
Study on the Use of a Variety of Plastic Materials in a Mixture of High Density Polyethylene (HDPE) in a Mixture Based on Wear AC-WC Layers (Asphalt Concrete Wearing Course)
}

\author{
Suprayitno, Sri Wiwoho Mudjanarko \\ Narotama University Surabaya \\ sri.wiwoho@narotama.ac.id
}

\begin{abstract}
Roads with flexible pavement are pavements that use asphalt as an aggregate binder, so they are much in demand rather than rigid pavement. Road infrastructure requires maintenance whose conditions must be maintained on an ongoing basis. The use of plastic packaging cannot be separated in everyday life. HDPE (High density polyethylene) is high density polyethylene. Based on the problem of the amount of used plastic waste currently available, this research is needed to find out how well the pavement uses the use of HDPE (High Density Polyethylene) plastic as mixed plastic waste. After testing the laboratory and analyzing it according to the General Highway Specifications for normal composition 1 without a mixture of $0 \%$, the asphalt content that meets all the requirements is estimated at asphalt level between 5.6\% - 6\%. Whereas in composition 2-4 with HPDE plastic waste $4 \%, 8 \%$, and $12 \%$. From the results of the research with 4 different compositions, it is obtained that the optimal asphalt content composition of HDPE plastic mixture is $0-12 \%$ which meets the VIM and stability an optimal $8 \%$ HDPE plastic mixture was obtained with an optimum asphalt content of $4.45 \%$
\end{abstract}

Keywords: Asphalt, Plastics, HDPE

\begin{tabular}{ccc}
\hline Received & Revised & Published \\
${\text { April } 11^{\text {th }}}^{2} 2019$ & June $14^{\text {th }} 2019$ & September $30^{\text {th }} 2019$ \\
\hline
\end{tabular}

\section{INTRODUCTION}

Roads are infrastructures made by humans to facilitate travel on land and the evenly distributed economic development in various regions of a country. Road infrastructure is a publicly owned economic asset that is very 
strategic for service levels and conditions must be maintained on an ongoing basis. HDPE can be produced with metallocene catalysts, ZieglerNatta catalysts, and chromium / silica catalysts.

HDPE is widely used as material for making milk bottles, bottles or detergent packaging, trash bins, margarine packaging and water pipes. Based on the above problems, this research is needed to find out how strong the pavement is by using HDPE (High Density Polyethylene) plastic waste as an ingredient in a hot asphalt mixture. Therefore, in an effort to utilize the plastic waste, the writer wants to do research by choosing the title of the Thesis "Study of Using Variations of HDPE (High Density Polyethylene) Plastic Material Mixes on Paved Mixtures for Asphalt Concrete Wearing Coarse (AC-WC) Mixture".

\section{LITERATURE REVIEW}

\section{Flexible pavement}

Flexible pavement (pavement), which is pavement using asphalt as a binding agent. Pavement layers are shouldering and spreading the burden of traffic to the subgrade. Flexible pavement is a road pavement that is commonly used in Indonesia. The types of flexible pavement layers commonly used in Indonesia include:

- Burtu (one layer of bitumen asphalt), a cover layer consisting of a layer of asphalt sprinkled with one layer of uniform gradation, with a maximum thickness of $2 \mathrm{~cm}$.

- Burda (double layer asphalt), is a cover layer consisting of asphalt layers sprinkled with aggregate which is done twice in succession with a maximum solid thickness of $3-5 \mathrm{~cm}$.

- Latasir (thin layer of asphalt sand), is a cover layer consisting of asphalt layers and gradated natural sand continuously mixed, spread and compacted with a thick thickness of 1-2 cm.

- Buras (asphalt sprinkles), is a cover layer consisting of asphalt layers of sand with a maximum grain size of $3 / 8$ inch.

- Latasbum (thin layer of pure asbuton), is a cover layer consisting of a mixture of asbuton and softeners with a certain ratio that is coolly mixed with a thick solid maximum of $1 \mathrm{~cm}$.

- Lataston (thin layer of asphalt concrete), known as Hot Roll Sheet (HRS), is a cover layer consisting of a mixture of lame graded aggregate, mineral filler (filler) and hard asphalt with a certain ratio, 
which is mixed and compacted in hot conditions. Dense thickness between $2.5-3 \mathrm{~cm}$. [1]

Table 1. Rough aggregate provisions

\begin{tabular}{|c|c|c|c|c|}
\hline \multicolumn{3}{|c|}{ Testing } & Standard & Value \\
\hline \multirow{2}{*}{$\begin{array}{l}\text { Conservation } \\
\text { of aggregate } \\
\text { form } \\
\text { of sodium } \\
\text { sulfate solution }\end{array}$} & \multicolumn{2}{|c|}{ natrium sulfat } & \multirow{2}{*}{ SNI 3407:2008 } & $\begin{array}{c}\text { Maks. } \\
12 \%\end{array}$ \\
\hline & \multicolumn{2}{|c|}{ magnesium sulfat } & & $\begin{array}{c}\text { Maks. } \\
18 \%\end{array}$ \\
\hline \multirow{4}{*}{$\begin{array}{l}\text { Abrasion with } \\
\text { Los Angeles } \\
\text { machine }\end{array}$} & \multirow{2}{*}{$\begin{array}{c}\text { Mix AC } \\
\text { Modification }\end{array}$} & $\begin{array}{l}100 \\
\text { the } \\
\text { round }\end{array}$ & \multirow{4}{*}{ SNI 2417:2008 } & $\begin{array}{c}\text { Maks. } \\
6 \%\end{array}$ \\
\hline & & $\begin{array}{l}500 \\
\text { the } \\
\text { round }\end{array}$ & & $\begin{array}{c}\text { Maks. } \\
30 \%\end{array}$ \\
\hline & \multirow{2}{*}{$\begin{array}{c}\text { All type } \\
\text { other graded } \\
\text { asphalt } \\
\text { mixture }\end{array}$} & $\begin{array}{l}100 \\
\text { the } \\
\text { round }\end{array}$ & & $\begin{array}{c}\text { Maks. } \\
8 \%\end{array}$ \\
\hline & & $\begin{array}{l}500 \\
\text { the } \\
\text { round }\end{array}$ & & $\begin{array}{c}\text { Maks. } \\
40 \%\end{array}$ \\
\hline \multicolumn{3}{|c|}{ Aggregate adhesion to asphalt } & SNI 2439:2011 & $\begin{array}{l}\text { Maks. } \\
95 \%\end{array}$ \\
\hline \multicolumn{3}{|c|}{ Broken Grain on Rough Aggregate } & SNI 7619:2012 & $95 / 90$ \\
\hline \multicolumn{3}{|c|}{ Max. Flat particles and Oval } & ASTM D4791 & $\begin{array}{c}\text { Maks. } \\
10 \%\end{array}$ \\
\hline \multicolumn{3}{|c|}{ Material escaped Sieve No. 200} & $\begin{array}{c}\text { SNI 03-4142- } \\
1996\end{array}$ & $\begin{array}{c}\text { Maks. } \\
2 \%\end{array}$ \\
\hline
\end{tabular}

Source: 2010 General Specifications Revision 2 DGH

Table 2. Nominal rough coarse measurements

\begin{tabular}{l|l|l} 
Testing & Standard & Value \\
\hline
\end{tabular}




\begin{tabular}{|l|c|c|}
\hline Sand Equivalent Value & SNI 03-4428-1997 & Min. 60\% \\
\hline Angularity with Cavity Level Test & SNI 03-6877-2002 & Min. 45\% \\
\hline $\begin{array}{l}\text { Clays of Clays and Grains - } \\
\text { grains } \\
\text { Easy to Break in Aggregate }\end{array}$ & SNI 03-4141-1996 & Maks 1\% \\
\hline $\begin{array}{l}\text { Aggregate Passed Ayakan No. } \\
200\end{array}$ & SNI ASTM C117:2012 & Maks. 10\% \\
\hline
\end{tabular}

Source: 2010 General Specifications Revision 2 DGH

\section{Asphalt}

The definition of asphalt is a black or dark brown material. At room temperature in the form of solid to slightly dense, if heated to a certain temperature can be soft / liquid so that it can wrap aggregate particles when making concrete asphalt mixture or can enter the pores in spraying / watering on road pavement.

\section{HDPE Plastic}

High-density polyethylene (HDPE) or high-density polyethylene (PEHD) is thermoplastic polyethylene made from petroleum. Sometimes it is called "alkathene" or "polythene" when used for pipes. With a high strength-todensity ratio, HDPE is used in the production of plastic bottles, corrosionresistant pipes, geomembranes, and wood plastics. HDPE is usually recycled, and has the number "2" as its resin identification code.

There are two plastic mixing techniques in asphalt mixes, namely:

1. Wet process (wet process), which is a method of mixing in which plastic is put into hot asphalt and stirred at high speed until it is homogeneous. This method requires quite large additional funds, including fuel, high speed mixer so that the resulting modified asphalt is quite a big difference compared to conventional asphalt.

2. The dry process (dry process), which is a way in which plastic is put into the aggregate which is heated at the temperature of the mixture, then hot asphalt is added. This method can be cheaper than the wet method, it's easier just to put plastic into the hot aggregate, without the need for other equipment to mix (mixer).

\section{Marshall Testing}


- VFWA is asphalt which functions to cover aggregate grains in solid asphalt concrete, or in other words, this VFWA is a percentage of the volume of asphalt concrete which becomes asphalt film or blanket. [2]

- Void In The Mix (VITM) is the pore volume that remains after the concrete mixture is compressed. VITM is needed for the shifting of aggregate points, due to additional compaction that occurs by repetition of traffic loads, or a place if asphalt becomes soft due to rising temperatures. [2]

- stability is the ability of pavement to accept traffic loads without permanent changes such as waves, grooves and bleeding. [2]

- Marshall Quotient is the quotient of stability to melt that is used to approach the level of stiffness or flexibility of the mixture. A high Marshall Quotient value indicates a high hard layer stiffness value. [2]

\section{Making a research schedule}

This research was conducted in approximately 4 months, the implementation schedule of the research testing process from beginning to end.

\section{RESULT AND DISCUSSION}

\section{Calculation and Analysis of Material Physical Tests}

Table 3. Test results for coarse aggregate filter analysis (10-15 $\mathrm{mm})$

\begin{tabular}{|l|c|c|c|c|}
\hline \multirow{2}{*}{ No } & \multicolumn{2}{|c|}{ Size Filter } & $\begin{array}{c}\text { Retained } \\
\text { Cumulativ } \\
\text { e }\end{array}$ & Cumulative \\
\cline { 2 - 5 } & \multirow{2}{*}{ ASTM } & SNI & Average & Average \\
\cline { 2 - 5 } & inc & $\mathbf{m m}$ & $\mathbf{( \% )}$ & $\mathbf{( \% )}$ \\
\hline 1 & $2 "$ & 50.80 & - & $\mathbf{1 0 0 . 0 0}$ \\
\hline 2 & $1 \frac{1}{2 "}{ }^{\prime \prime}$ & 37.50 & - & $\mathbf{1 0 0 . 0 0}$ \\
\hline 3 & $1 "$ & 25.40 & - & $\mathbf{1 0 0 . 0 0}$ \\
\hline 4 & $3 / 4 "$ & 19.10 & - & $\mathbf{1 0 0 . 0 0}$ \\
\hline 5 & $1 / 2 "$ & 12.50 & 7.00 & $\mathbf{9 3 . 0 0}$ \\
\hline 6 & $3 / 8 "$ & 9.50 & 74.55 & $\mathbf{2 5 . 4 5}$ \\
\hline 7 & No. 4 & 4.75 & 99.37 & $\mathbf{0 . 6 3}$ \\
\hline
\end{tabular}


THE SPIRIT OF SOCIETY JOURNAL

International Joumal of Society Development and Engagement

ISSN : 2597-4777 (Online) - ISSN : 2597-4742 (Print)

This work is licensed under a Creative Commons Attrib ution-ShareAlike 4.0 International License.

\begin{tabular}{|c|c|c|c|c|}
8 & No. 8 & 2.36 & 99.64 & $\mathbf{0 . 3 6}$ \\
\hline 9 & No. 16 & 1.18 & 99.90 & $\mathbf{0 . 1 0}$ \\
\hline 10 & No. 30 & 0.60 & 100.00 & $\mathbf{0 . 0 0}$ \\
\hline 11 & No. 50 & 0.30 & 100.00 & $\mathbf{0 . 0 0}$ \\
\hline 12 & No. 100 & 0.15 & 100.00 & $\mathbf{0 . 0 0}$ \\
\hline 13 & No. 200 & 0.008 & 100.00 & $\mathbf{0 . 0 0}$ \\
\hline
\end{tabular}

Table 4. Physical test results for asphalt pen 60/70

\begin{tabular}{|l|l|c|c|}
\hline NO & DESCRIPTION & $\begin{array}{c}\text { TEST } \\
\text { RESULTS } \\
\text { ASPAL PEN } \\
60 / 70\end{array}$ & EQUIREMENTS \\
\hline 1. & $\begin{array}{l}\text { Penetration at } 25^{\circ} \mathrm{C} \\
(\mathrm{dmm})\end{array}$ & 61.9 & $60-70$ \\
\hline 2. & $\begin{array}{l}\text { Softening Point } \\
\left({ }^{\circ} \mathrm{C}\right)\end{array}$ & 49.2 & $\geq 48$ \\
\hline 3. & $\begin{array}{l}\text { Ductility at } 25^{\circ} \mathrm{C} \\
\text { (cm) }\end{array}$ & $>140$ & $\geq 100$ \\
\hline 4. & Flash Point $\left({ }^{\circ} \mathrm{C}\right)$ & 288 & $\geq 232$ \\
\hline 5. & Specific Gravity & 1,032 & $\geq 1,0$ \\
\hline
\end{tabular}

The combined grading results of aggregate and filler can be seen in Figure 1 below: 


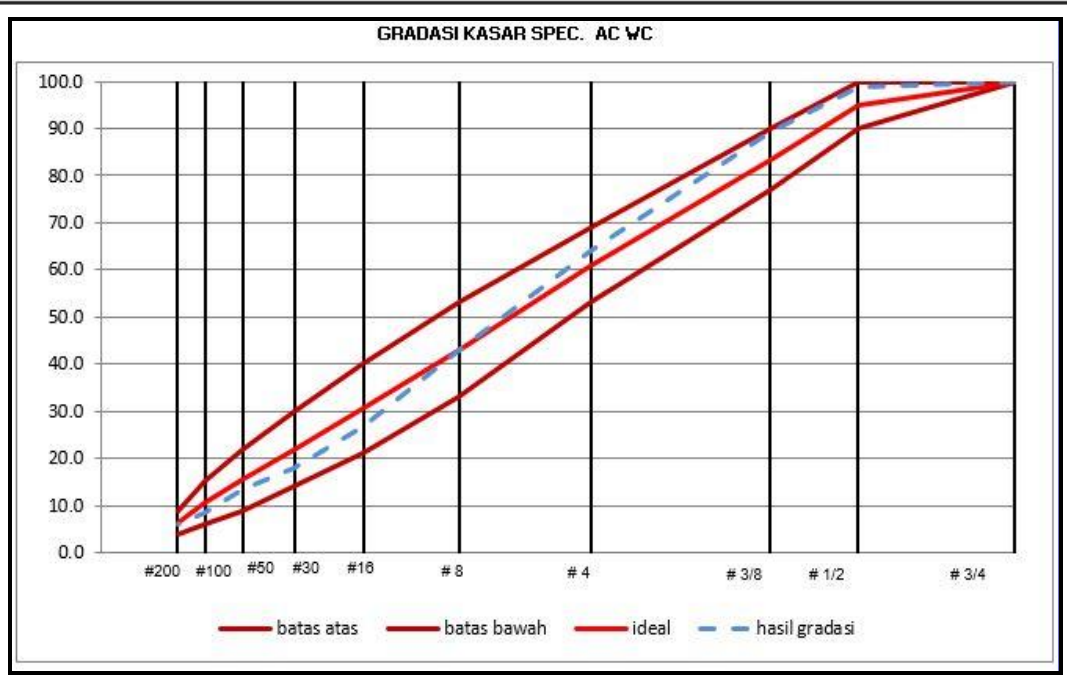

Figure 1. Grading aggregate gradation graph and filler material

\section{Calculation of Asphalt Levels Composition Plan for test specimens}

$$
\begin{gathered}
\% \mathrm{CA}=(100-43,0) \%=57,0 \% \\
\% \mathrm{FA}=(43,0-6,2) \%=36,8 \% \\
\% \mathrm{FF}=6,2 \% \\
\mathrm{~Pb}=0,035 \times(\% \mathrm{CA})+0,045 \times(\% \mathrm{FA})+0,18 \times(\% \mathrm{FF})+\mathrm{K} \\
\mathrm{Pb}=(0,035 \times 57 \%)+(0,045 \times 36,8 \%)+(0,18 \times 6,2 \%)+1 \\
\mathrm{~Pb}=5,8 \%
\end{gathered}
$$

Thus the hot asphalt mixture test specimen is made with the asphalt content of the plan as follows:

$$
\begin{array}{ccc}
\mathrm{Pb}-1 \% & =5,8 \%-1 \% & =4,8 \% \\
\mathrm{~Pb}-0,5 \% & =5,8 \%-0,5 \% & =5,3 \% \\
\mathrm{~Pb} & =5,8 \% & =5,8 \% \\
\mathrm{~Pb}+0,5 \% & =5,8 \%+0,5 \% & =6,3 \% \\
\mathrm{~Pb}+1 \% & =5,8 \%+1 \% & =6,8 \%
\end{array}
$$

After obtaining the asphalt content of the plan, the marshal test object and the refusal test object are planned by adding variations in the percentage of HPDE plastic waste in each composition, namely $4 \%, 8 \%, 12 \%$ of the total asphalt weight of each mixture. 




Figure 2. The process of mixing hot asphalt test specimens using plastic waste (source: research results in laboratory)

The test results of the hot asphalt mixture specimens using HPDE plastic waste on the wear layer (AC-WC) were obtained from testing the asphalt mixture with marshall devices in accordance with SNI 06-2489-1991.

Table 5. Marshall test results for composition 1 test with a normal mixture of $0 \%$

\begin{tabular}{|c|c|c|c|c|c|c|c|c|}
\hline \multirow{2}{*}{ No. } & \multirow{2}{*}{$\begin{array}{c}\text { Mixture } \\
\text { Characteristics }\end{array}$} & \multicolumn{5}{|c|}{ Estimated } & \multirow{2}{*}{ Unit } & \multirow{2}{*}{$\begin{array}{l}\text { Specificati } \\
\text { ons }\end{array}$} \\
\hline & & 4,8 & 5,3 & 5,8 & 6,3 & 6,8 & & \\
\hline 1 & $\begin{array}{l}\text { Cavity in the } \\
\text { mixture (VIM) }\end{array}$ & 8,75 & 6,58 & 4,71 & 2,06 & 1,8 & $\%$ & $\begin{array}{l}\text { Min. } 3 \text { dan } \\
\text { Maks. } 5\end{array}$ \\
\hline 2 & $\begin{array}{l}\text { Cavity Against } \\
\text { Aggregate } \\
\text { (VMA) }\end{array}$ & $\begin{array}{c}17,6 \\
7\end{array}$ & $\begin{array}{c}16,7 \\
8\end{array}$ & $\begin{array}{c}16,1 \\
7\end{array}$ & $\begin{array}{c}14,9 \\
2\end{array}$ & $\begin{array}{l}15 \\
76\end{array}$ & $\%$ & Min. 15 \\
\hline 3 & Density & $\begin{array}{c}2,26 \\
9\end{array}$ & $\begin{array}{c}2,30 \\
6\end{array}$ & $\begin{array}{c}2,33 \\
5\end{array}$ & $\begin{array}{c}2,38 \\
2\end{array}$ & $\begin{array}{l}2,3 \\
71\end{array}$ & & \\
\hline 4 & $\begin{array}{l}\text { Cavity Filled } \\
\text { Asphalt (VFB) }\end{array}$ & $\begin{array}{c}50,5 \\
0\end{array}$ & $\begin{array}{c}60,7 \\
7\end{array}$ & $\begin{array}{c}70,8 \\
7\end{array}$ & $\begin{array}{c}86,2 \\
0\end{array}$ & $\begin{array}{l}88, \\
55\end{array}$ & $\%$ & Min.65 \\
\hline 5 & Melting (flow) & 2 & 2,95 & 2,95 & 3,75 & 3,3 & $\mathrm{~mm}$ & Min. 3 \\
\hline 6 & $\begin{array}{l}\text { Marshall } \\
\text { Quotient }\end{array}$ & 725 & $\begin{array}{c}450 \\
8\end{array}$ & $\begin{array}{c}472 \\
5\end{array}$ & $\begin{array}{c}333 \\
5\end{array}$ & $\begin{array}{c}307 \\
, 5\end{array}$ & $\begin{array}{c}\mathrm{kg} / \mathrm{m} \\
\mathrm{m}\end{array}$ & Min. 300 \\
\hline 7 & $\begin{array}{l}\text { Effective Asphalt } \\
\text { Levels }\end{array}$ & 4,06 & 4,56 & 5,07 & 5,57 & $\begin{array}{c}6,0 \\
7\end{array}$ & $\%$ & Min. 4,3 \\
\hline 8 & $\begin{array}{l}\text { Marshall } \\
\text { Stability }\end{array}$ & 1450 & $\begin{array}{c}1326 \\
, 3\end{array}$ & 1391 & 1237 & $\begin{array}{c}101 \\
4\end{array}$ & kg & Min. 1000 \\
\hline
\end{tabular}


Table 6. Marshall test test composition 3 with a mixture of $8 \%$ hdpe plastic waste

\begin{tabular}{|c|c|c|c|c|c|c|c|c|}
\hline \multirow{2}{*}{ No. } & \multirow{2}{*}{$\begin{array}{c}\text { Mixture } \\
\text { Characteristic } \\
\text { s }\end{array}$} & \multicolumn{5}{|c|}{ Estimated } & \multirow{2}{*}{ Unit } & \multirow{2}{*}{$\begin{array}{l}\text { Specificati } \\
\text { ons }\end{array}$} \\
\hline & & 4,8 & 5,3 & 5,8 & 6,3 & 6,8 & & \\
\hline 1 & $\begin{array}{l}\text { Cavity in the } \\
\text { mixture (VIM) }\end{array}$ & 4,50 & 3,67 & 3,48 & 2,76 & 2,55 & $\%$ & $\begin{array}{l}\text { Min. } 3 \text { dan } \\
\text { Maks. } 5\end{array}$ \\
\hline 2 & $\begin{array}{l}\text { Cavity Against } \\
\text { Aggregate } \\
\text { (VMA) }\end{array}$ & $\begin{array}{c}13,8 \\
4\end{array}$ & $\begin{array}{c}14,1 \\
8\end{array}$ & $\begin{array}{c}15,0 \\
9\end{array}$ & $\begin{array}{c}15,5 \\
2\end{array}$ & $\begin{array}{c}16,4 \\
0\end{array}$ & $\%$ & Min. 15 \\
\hline 3 & Density & $\begin{array}{c}2,37 \\
5\end{array}$ & $\begin{array}{c}2,37 \\
8\end{array}$ & $\begin{array}{c}2,36 \\
5\end{array}$ & $\begin{array}{c}2,36 \\
5\end{array}$ & $\begin{array}{c}2,35 \\
3\end{array}$ & & \\
\hline 4 & $\begin{array}{ll}\text { Cavity } & \text { Filled } \\
\text { Asphalt (VFB) }\end{array}$ & $\begin{array}{c}67,5 \\
0\end{array}$ & $\begin{array}{c}74,1 \\
2\end{array}$ & $\begin{array}{c}76,9 \\
6\end{array}$ & $\begin{array}{c}82,2 \\
5\end{array}$ & $\begin{array}{c}84,4 \\
3\end{array}$ & $\%$ & Min.65 \\
\hline 5 & Melting (flow) & 3,00 & 2,35 & 2,85 & 3,30 & 3,80 & $\mathrm{~mm}$ & Min. 3 \\
\hline 6 & $\begin{array}{l}\text { Marshall } \\
\text { Quotient }\end{array}$ & $\begin{array}{c}508 \\
3\end{array}$ & $\begin{array}{c}607 \\
3\end{array}$ & $\begin{array}{c}497 \\
4\end{array}$ & $\begin{array}{c}373 \\
3\end{array}$ & 260 & $\underset{\mathrm{m}}{\mathrm{kg} / \mathrm{m}}$ & Min. 300 \\
\hline 7 & $\begin{array}{l}\text { Effective } \\
\text { Asphalt Levels }\end{array}$ & 4,06 & 4,56 & 5,07 & 5,57 & 6,07 & $\%$ & Min. 4,3 \\
\hline 8 & $\begin{array}{l}\text { Marshall } \\
\text { Stability }\end{array}$ & $\begin{array}{c}1525 \\
, 0 \\
\end{array}$ & $\begin{array}{c}1406 \\
, 3 \\
\end{array}$ & $\begin{array}{c}1417 \\
, 0 \\
\end{array}$ & $\begin{array}{c}1224 \\
, 0 \\
\end{array}$ & 988 & $\mathrm{~kg}$ & Min. 1000 \\
\hline
\end{tabular}

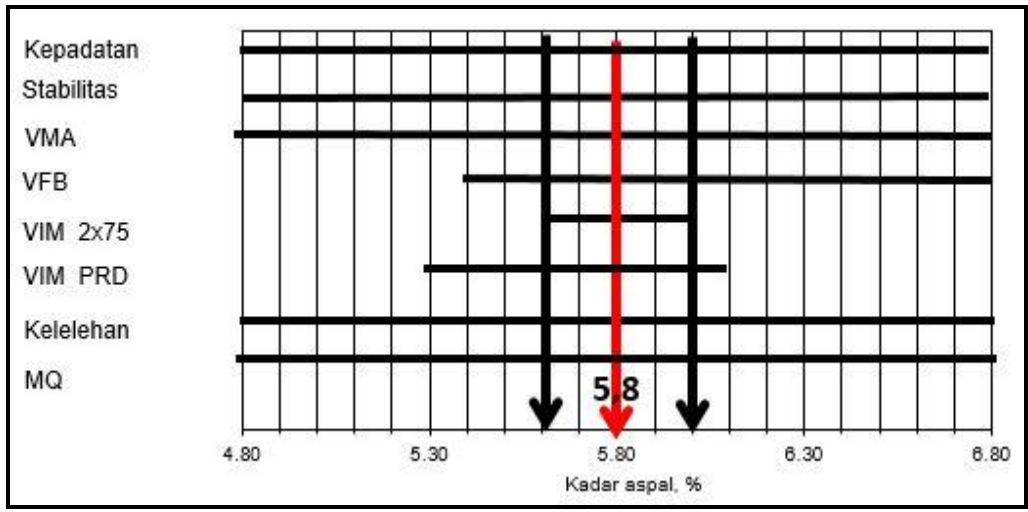

Figure 3. Graph of Optimum Asphalt Levels of Test Object Composition 1 with a normal mixture of $0 \%$ 


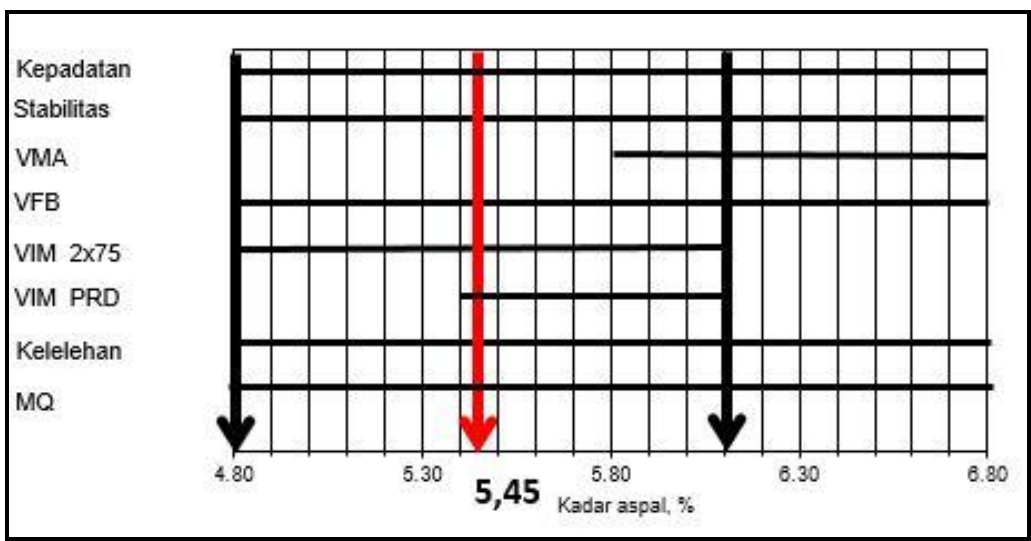

Figure 4. Graph of optimum asphalt content of specimen 3 with a mixture of $8 \%$ hpde plastic waste

\section{CONCLUSIONS}

After conducting research in the laboratory and analyzing the results of these experiments it can be concluded:

1. For composition 1 normal mixture of $0 \%$, the asphalt content that meets all the requirements is the estimated asphalt content between $5.6 \%$ $6 \%$. Whereas in composition 2 with the addition of $4 \%$ HDPE plastic the estimated asphalt content that meets all the requirements is the estimated asphalt content between $4.8 \%-5.7 \%$. Then composition 3 with the addition of $8 \%$ HDPE plastic, the estimated asphalt content that meets all the requirements is an estimated asphalt content between $4.8 \%-6.1 \%$, and for composition 4 with an additional HDPE plastic $12 \%$, the estimated asphalt content that meets all the requirements is the estimated asphalt level between $5.5 \%-6.2 \%$.

2. The optimum asphalt content for composition 1 with a normal composition of $0 \%$ is $5.8 \%$. Then the optimum asphalt content for composition 2 with a mixture of $4 \%$ HDPE plastic is $5.25 \%$. While the optimum asphalt content for composition 3 with $8 \%$ HDPE plastic mixture is $5.45 \%$. And for composition 4 with the addition of a $12 \%$ HDPE plastic mixture produces an Optimum Asphalt Level of $5.85 \%$. Among the composition of the $0-12 \%$ HDPE plastic mixture that meets the VIM and Stability, the optimum $8 \%$ HDPE plastic mixture is obtained with an optimum asphalt content of $4.45 \%$. 


\section{REFERENCE}

S. Sukirman, Pavement Flexural Highway, (1992)

S. Sukirman, Planning for Flexible Pavement Structure Thickness, (2010)

Department of Public Works, Testing Methods About Fine and Rough Aggregate Filter Analysis SNI 03-1968, (1990)

Department of Public Works, Marshall Testing Method SNI 06 - (2489) (1991)

Directorate General of Highways, Special Specifications for Interim Section SKh-1.6.10 Hot Asphalt Mixture Using Plastic Waste, (2017)

Sri Wiwoho Mudjanarko, Plastic waste of low density polyethylene (LDPE) types in asphalt mixture. Paper. In: Proceedings of the International Conference on Industrial Engineering and Operations Management, (2018) 